\title{
Emergency department sedation guidelines: a tale of two specialties
}

\author{
Grant Innes, MD
}

E mergency department (ED) procedural sedation is a contentious issue that evokes more emotion than logic among its discussants. Dr. Del Donald's letter in this issue ${ }^{1}$ is representative of several communications I've had with Canadian emergency physicians over the last few months.

The same script is acted out repeatedly in hospitals across the country. Emergency physicians sedate patients for painful ED procedures. Anesthetists decry the practice as dangerous and unnecessary, and take whatever steps they feel are necessary to restrict the process. The Canadian Association of Emergency Physicians' (CAEP) recently published procedural sedation guidelines ${ }^{2}$ have perhaps stirred the pot even more.

As members of a horizontally-integrated discipline, emergency physicians share patient care responsibilities with many other specialists. While emergency physicians must define practice standards in the ED, we routinely engage other specialty groups in consensus-building processes to establish "acceptable" practice patterns. This was how the CAEP sedation guidelines began.

CAEP's initial goal was to enlist the support of the Canadian Anaesthetists' Society (CAS) and develop joint

St. Paul's Hospital, Vancouver, BC; Editor, CJEM
CAEP/CAS guidelines for ED procedural sedation. While we were not convinced the CAS recognized the importance of ED sedation or the need for ED sedation guidelines, we felt that a consensus document would go a long way toward ending what are widely viewed as "turf" battles over sedation.

The process began in March of 1996, when representatives of CAEP and CAS teleconferenced to identify contentious issues and define a plan for guideline development. The CAEP working committee subsequently prepared a first draft and circulated it for comment. Based on the group's feedback, the sedation document was revised and CAS reviewers appraised the second draft. Further concerns were addressed in a third revision, which I presented at a June 1997 CAS Standards Committee meeting in Vancouver.

In the end, the CAS was unwilling to endorse CAEP's guidelines. Therefore, while it is accurate to say that they did not approve of the guidelines, it is also accurate to say they were involved from the start and had a substantial impact on the final product. It is clear now that the concept of joint CAS/CAEP guidelines was a pipe dream. The average anesthetist has about as much insight into the ED environment as I have into the O.R. environment. Anesthetists, as a group, are uncomfortable with the concept of emergency physicians sedating patients. For the CAS Board or
Standards Committee to endorse CAEP's guidelines would be to endorse ED sedation, and this would not be a tenable position for them. Therefore, regardless of the quality or content of ED guidelines, and irrespective of their potential to increase the safety of ED sedation, I doubt that any anesthesia board or standards committee could endorse them and survive. It goes too much against the grain.

The CAS representatives who participated in the process and reviewed the evolving guidelines were nice people who meant well. They provided useful comments and probably improved the quality of our final product. It is my opinion now, however, that there was never any chance that the CAS would endorse sedation guidelines for the ED. Clues to the final outcome appeared early in the process, when CAS reviewers seemed to dramatically misinterpret our draft guidelines. It was as if the guidelines were so distasteful that objective evaluation was impossible.

The CAS's refusal to endorse CAEP's guidelines will be viewed by some as evidence that the guidelines are flawed or dangerous. To dispel this notion, it is important to air the CAS's specific concerns and the emergency working group's responses to them - responses that were provided to the CAS prior to their decision not to endorse.

Continued on page 136 


\title{
Directives de sédation au département d'urgence : Il était une fois... deux spécialités
}

\author{
Grant Innes, MD
}

$\mathrm{L}$ a sédation avant une intervention à l'urgence est une question controversée où les émotions l'emportent sur la logique au sein des parties impliquées. La lettre du $\mathrm{D}^{\mathrm{r}}$ Del Donald dans ce numéro ${ }^{1}$ est représentative des nombreux entretiens que j'ai eus avec les urgentologues canadiens au cours des derniers mois.

Le même scénario se répète dans les hôpitaux d'un bout à l'autre du pays. Les urgentologues administrent un anesthésique aux patients pour les interventions douloureuses à l'urgence.

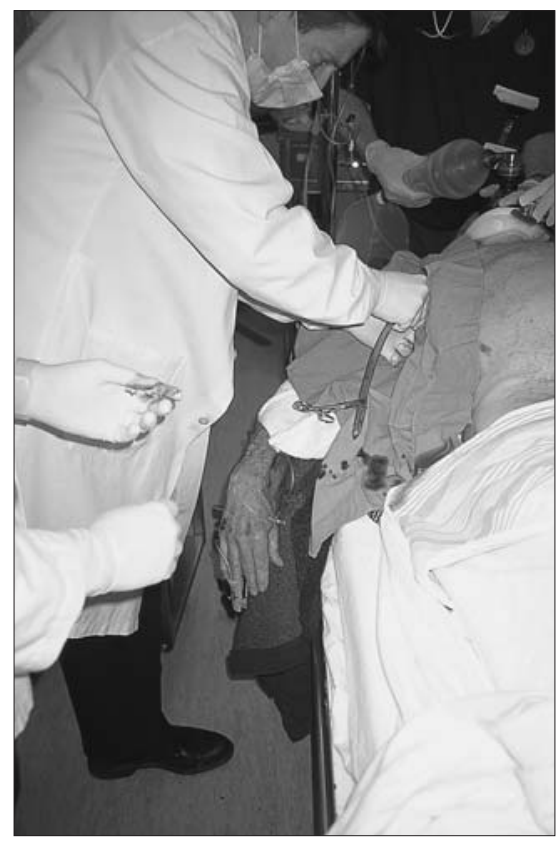

Un drain thoracique. Les interventions douloureuses : un aspect de la médecine d'urgence.

St. Paul's Hospital, Vancouver, BC; Rédacteur, JCMU
Les anesthésistes qualifient cette pratique de dangereuse et d'inutile et prennent toutes les mesures qu'ils jugent nécessaires pour la décourager. La publication récente par l'Association canadienne des médecins d'urgence (ACMU) de directives de sédation avant une intervention ${ }^{2}$ a peut-être attisé davantage la controverse.

En tant que membres d'une discipline à intégration horizontale, les urgentologues partagent les responsabilités des soins aux patients avec plusieurs spécialistes. Les médecins d'urgence incluent de façon routinière d'autres groupes de spécialistes dans le processus d'établissement d'un consensus pour la définition de normes de pratique acceptables. C'est ainsi qu'a été amorcée l'élaboration des directives de sédation de l'ACMU.

L'objectif initial de l'ACMU était d'obtenir l'appui de la Société canadienne d'anesthésie (SCA) et d'établir des directives conjointes ACMU/SCA pour la sédation avant une intervention à l'urgence. Bien que nous n'étions pas convaincus que la SCA reconnaissait l'importance de la sédation à l'urgence ou la nécessité d'écrire des directives de sédation à l'urgence, nous estimions qu'un document de consensus contribuerait à mettre fin aux luttes de «territoire» au sujet de la sédation.

Le processus fut mis en branle en mars 1996, lorsque des représentants de l'ACMU et de la SCA tinrent une conférence téléphonique pour identifier les questions litigieuses et définir un plan d'élaboration des directives. Le comité de travail de l'ACMU prépara par la suite un document préliminaire et en fit la distribution pour commentaire. À partir des recommandations du groupe, le document sur la sédation fut révisé et les critiques de la SCA prirent connaissance de la deuxième version. Des modifications additionnelles furent apportées pour créer une troisième version que je présentai lors d'une réunion du Comité des normes de la SCA en juin 1997 à Vancouver.

Finalement, la SCA avait des réticences à endosser les directives de l'ACMU. Par conséquent, bien qu'il soit exact de dire qu'elle n'a pas approuvé ces directives, il est également exact de dire qu'elle était impliquée dans le processus dès le départ et qu'elle avait eu une influence importante sur le produit final. Il est évident aujourd'hui que le concept de définition conjointe de directives ACMU/SCA n'était qu'un projet chimérique. L'anesthésiste moyen connaît à peu près autant l'environnement de l'urgence que moi je connais l'environnement de la salle d'opération. Les anesthésistes, en tant que groupe, n'aiment pas l'idée que les urgentologues puissent administrer des anesthésiques aux patients. Pour le Conseil d'administration ou le Comité des normes de la SCA, le fait d'endosser les directives de l'ACMU équivaut à endosser la sédation à l'urgence, position non défendable pour eux. Par conséquent, indépen- 
damment de la qualité ou du contenu des directives à l'urgence, et de l'amélioration potentielle de la sécurité de la sédation à l'urgence, je doute qu'un Conseils d'anesthésistes ou un comité des normes puisse endosser ces directives et survivre. C'est trop à l'encontre de leur nature.

Les représentants de la SCA qui ont participé au processus et révisé les directives étaient des types sympathiques avec de bonnes intentions. Ils nous ont fait des commentaires utiles et ont probablement contribué à l'amélioration de la qualité de notre produit final. Cependant, il est de mon avis qu'il n'y avait aucune chance que la SCA endosse nos directives de sédation à l'urgence. Des indices de ce dénouement sont apparus tôt dans le processus lorsque les critiques de la SCA ont semblé comprendre tout de travers nos directives préliminaires. C'était comme si celles-ci eussent été tellement déplaisantes qu'il leur était impossible de les évaluer objectivement.
Le refus de la SCA d'endosser les directives de l'ACMU sera vu par certains comme la preuve que les directives sont imparfaites ou dangereuses. Afin de dissiper cette notion, il est important de faire connaître les inquiétudes spécifiques de la SCA ainsi que les réponses fournies par le groupe de travail des urgentologues et ce, avant que celle-ci ne décide de ne pas endosser les directives.

Suite à la page 136 (en Anglais)

\title{
Call for Abstracts 8th International Conference on Emergency Medicine
}

\author{
May 4-7, 2000 \\ Boston, Massachusetts, USA
}

Deadline for submission is November 1, 1999. Decisions mailed by January 15, 2000.

The 8th International Conference on Emergency Medicine (8th ICEM) is now accepting abstracts for oral or poster presentations during the conference. This international conference is hosted by the American College of Emergency Physicians (ACEP). The British Association for Accident and Emergency Medicine will manage its own Call for Abstracts. Please contact BAEM directly for information about their deadlines and submission standards. All other participants should respond to this invitation and send their abstract submissions to Dr. Marsha Ford.

Seventeen educational tracks include: Care Delivery Systems, Administration, International Development, Disaster Medicine, Infectious Diseases, Medical Information Systems, Pediatrics, Trauma, Obstetrics/Gynecology, Toxicology, Medical Imaging, Out-of-Hospital/Emergency Medical Services, Education, International Societal Issues, Environmental Medicine, Internal Medicine, and Anesthesia/Airway/Analgesia.

Abstract submissions to both the 1999 ACEP Research Forum as well as the 2000 Society for Academic Emergency Medicine (SAEM) Conference may also be submitted for consideration to the 8th ICEM without jeopardy.

Information on abstract format, cover sheet and guidelines may be obtained four ways: a) ACEP On FAX at 800-406-2237, document 80159 b) e-mail your request to edmeetings@acep.org, c) visit our website at www.acep.org/8thinter/8thinter.htm, or d) call 800-798-1822, touch 6, or 972-550-0911.

Submit original and eight copies of your abstract to: Marsha Ford, MD, FACEP, 8th ICEM Conference Coordinator, American College of Emergency Physicians, P.O. Box 619911, Dallas, Texas, 75261-9911. Street address for express shipping: 1125 Executive Circle, Irving, Texas, 75038-2522.

Submission in electronic format (Microsoft Word or text file) is required. Abstracts are limited to 200 words. Submit with one inch margins and double spacing on $8 \frac{1}{2} \times 11$ paper. Font should be at least 10 point. Abstracts submitted to the Society for Academic Emergency Medicine (SAEM) may use the their format. Abstracts must include the Abstract cover sheet, found quarterly in the Annals of Emergency Medicine and ACEP's website at www.acep.org.

The Annals of Emergency Medicine, the official journal of the American College of Emergency Physicians, will publish all accepted abstracts in the May 2000 issue. 


\title{
ED sedation guidelines: a tale of two specialties
}

\author{
Continued from page 88
}

\section{CAS concerns about the CAEP pro- cedural sedation guidelines}

\section{CAS concern}

The [CAEP] guidelines cannot be endorsed because they "encompass the induction of general anesthesia." CAS reviewers cited the following statement as evidence that we advocate general anesthesia in the ED.

"If deep sedation is performed, it requires the same level of monitoring that would be provided in the O.R."

\section{Response}

This phrase, which is in fact a JCAHO (Joint Commission on Accreditation of Healthcare Organizations) recommendation, ${ }^{3}$ states that, if a practitioner elects to induce deep sedation, they must be prepared to provide the same level of care and monitoring that would be available in the O.R. It is cautionary, not encouraging, and is meant to ensure that if deep sedation is performed, it is performed with safety in mind. The context of this phrase further clarifies that we discourage general anesthesia in the ED, with the following statements:

1. "Deep sedation is usually not necessary."

2. "In clinical situations where deep sedation is thought to be appropriate, the practitioner should first consider transferring the patient to the operating room or should choose a safer technique."

\section{Action}

We offered to reword the passage if it seemed confusing.

\section{CAS concern}

The CAS reviewer pointed out that "general anesthesia is indicated only for patients requiring endotracheal intubation, cardioversion, etc."

\section{Response}

"We agree. Wholeheartedly. General anesthesia is not optimal, and is unnecessary for most ED procedures. This is stated in our document."

\section{Action}

None required.

\section{CAS concern}

The reviewer felt the guidelines should place more emphasis on local anesthesia.

\section{Response}

Emergency physicians "perform a vast majority of emergency department procedures using only local anesthesia. This will not change. But these are guidelines for the use of procedural sedation, not local anesthesia."

\section{Action}

None required.

\section{CAS concern}

"We [CAS] cannot be co-sponsors of guidelines that endorse induction of general anesthesia by nonanesthetist physicians who simultaneously perform even brief diagnostic or therapeutic procedures."

\section{Response}

"We reiterate that, except in specific circumstances like intubation or cardioversion, emergency physicians do not want to induce general anesthesia. These guidelines state clearly, in 2 separate sections, that it is rarely appropriate to do so."

\section{Action}

We clarified in the guidelines that, if a state equivalent to general anesthesia is induced (e.g., for electrical cardioversion), the physician performing the sedation should not simultaneously perform the therapeutic procedure.

\section{CAS concern}

The CAS reviewer decried the use of "general anesthesia and paralysis," specifically mentioning the use of ketamine for rapid sequence induction (RSI) of asthmatics.

\section{Response}

"Canadian emergency physicians have used rapid sequence induction with paralysis for 15 years. It is, and will remain the procedure of choice for ED airway management. This is not an inappropriate ED technique."

\section{Action}

None required. While mentioned in the first draft, ketamine and RSI are not specifically discussed in the final guidelines.

\section{CAS concern}

The reviewers felt that ED physicians lack critical care skills and that the guidelines document "does not suggest limits [for practitioners] or define competencies, and has the potential to condone unsafe practices."

\section{Response}

We acknowledged that, while all emergency physicians have critical care skills, not all physicians in emergency departments are trained emergency physicians. We disagreed regarding the likelihood that the guidelines would condone unsafe practices.

"We have exactly the opposite perspective on this matter. The reality is that, today, physicians with a wide range of abilities are sedating ED patients with everything from morphine and diazepam to chloral hydrate to thiopental. Currently, there are no consistent limits or guidelines for physicians in emergency departments. We are attempting to introduce some. 
Contrary to what your reviewer says, our document ${ }^{2}$ does specify several limitations, as follows:

1. Lack of experience in airway management or advanced life support is a contraindication to sedation and analgesia (p. 148).

2. Lack of familiarity with medications being administered for sedation and analgesia is a contraindication to sedation (p. 148).

3. Lack of appropriate monitoring equipment is a contraindication to sedation and analgesia (p. 148).

4. Inability to monitor the patient during the procedure and recovery period is a contraindication to sedation and analgesia (p. 148).

5. A physician capable of airway management must be present during the sedation process (p. 149).

6. Practitioners should not sedate patients unless they are confident in their ability to deal with the possible complications (p. 149). The document specifies the potential complications in 23 places.

7. A physician competent at sedation and analgesia as well as advanced life support and airway management must be present in the department throughout the procedure and recovery period (p. 150).

8. Physicians performing procedural sedation should understand the pharmacology of the drugs they are administering and must be familiar with any relevant antagonists (p. 150).

"The 'limitations' specified in the CAEP document are more restrictive than those used by other specialist groups (e.g., gastroenterologists) who provide sedation outside the O.R. ${ }^{4-9}$ These limitations are also more restrictive than those specified in the American Society of Anesthesiologists (ASA) practice guidelines for sedation and analgesia by non-anesthesiologists. ${ }^{5}$ The ASA guidelines recommend that the practitioner should understand the pharmacology of the agents administered and the role of pharmacologic antagonists, should be capable of establishing a patent airway and positive pressure ventilation, should have a means for summoning assistance, and that an individual with advanced life support (ALS) skills be immediately available.

The CAEP guidelines indicate that physicians performing sedation should actually possess the defined skills rather than summoning someone who does.

"So while it is true that not all physicians in emergency departments have critical care skills, the only way an 'unskilled' physician could perform procedural sedation is by violating several of the specific limitations laid out in this document. The document condones safe practices, not unsafe ones, as your reviewer suggests."

\section{Action}

None required.

\section{CAS concern}

The CAS reviewers felt that our guidelines should indicate that deep sedation is undesirable in most instances and may compromise cardiovascular-respiratory status.

\section{Response}

"We agree. These exact points are stated several times in the document." Action

We agreed to reword the document if this concept was unclear.

\section{CAS concern}

The CAS reviewer felt that our monitoring guidelines should be consistent with CAS guidelines.

\section{Response}

"The guidelines in our document were taken from the ASA guidelines. ${ }^{5}$ They include monitoring level of consciousness, ventilatory function, pulse oximetry with variable pitch beep, and blood pressure. Above and beyond what the
ASA guidelines recommend, we specify pulse and respiratory rate monitoring.

"The ASA guidelines require ECG [electrocardiogram] monitoring for patients with significant cardiovascular disease or during procedures where arrhythmias are anticipated. The CAEP guidelines require heart rate monitoring and specify that only ASA Class 1 and 2 patients are eligible for elective sedation. From a monitoring perspective, the CAEP guidelines are not only compatible with ASA guidelines, but slightly more restrictive."

\section{Action}

We agreed to modify our guidelines if they were poorly stated.

\section{CAS concern}

The CAS reviewer stated that our guidelines "do not require pulse oximetry."

\section{Response}

In fact they do. The CAEP guidelines state clearly that "all patients sedated to the extent that their eyes are closed require heart rate, blood pressure, and oxygen saturation monitoring, preferably with oximeters that provide variable pitched beep." Page $150^{2}$ indicates that this monitoring should continue until the patient is fully awake. Pulse oximetry is also included on our pre-sedation checklist.

\section{Action}

None necessary.

\section{CAS concern}

The reviewer suggests we should list contraindications for medical conditions such as severe chronic obstructive pulmonary disease (COPD).

\section{Response}

"Rather than list every possible disease and contraindication, we have taken the same approach you use, and appended the ASA Physical Status Classification. We specified that, for elective procedures, emergency physicians should only sedate Class 1 or 2 patients. 
Emergency procedures (thoracostomy, intubation, cardioversion, etc) are necessary regardless of ASA status."

\section{Action}

None required.

\section{CAS concern}

The reviewer noted that "intravenous titration is the only way to achieve a given sedation endpoint."

\section{Response}

The CAEP sedation guidelines indicated that "intravenous titration is the best way to achieve a given endpoint."

\section{Action}

The reviewer is correct. The wording was changed in the guidelines.

\section{CAS concern}

The reviewer noted that the ASA fasting guidelines are for elective procedures.

\section{Response}

"We specified this clearly under "Presedation Preparation" and dealt in detail with the issue of emergent vs. elective sedation."

\section{Action}

None required.

\section{CAS concern}

The reviewer felt we had not adequately defined the "additional qualified support person."

\section{Response}

"The CAEP guidelines document indicates that this person will 'usually be a physician or nurse.' The ASA guidelines ${ }^{5}$ state only that a 'designated individual other than the person performing the procedure' should be present. The CAEP document, again, is slightly more restrictive than the ASA Guidelines."

\section{Action}

We agreed to discuss "appropriate qualifications" if necessary.

\section{CAS concern}

The reviewer felt we must define "regular intervals" for recording monitored parameters.

\section{Response}

"We can do this, however, again, we quoted the ASA guidelines directly in making our recommendation." 5

\section{CAS concern}

The reviewer felt that intravenous (IV) access is mandatory in all cases where patients are sedated.

\section{Response}

"We disagree. We believe there are situations where IV access is unnecessary. Mandatory IV access will require further discussion."

\section{Action}

None taken.

\section{CAS concern}

The reviewer suggests we made the following factual errors:

1. We suggested that diazepam has slower onset and longer duration than midazolam.

\section{Response}

"We are aware this is controversial, but the statement is based on more than personal experience. Wright ${ }^{10}$ demonstrated that, when used for ED sedation and titrated to clinical effect, midazolam provided significantly earlier sedation and a more rapid return to baseline function than diazepam."

2. We failed to state that barbiturates are anti-analgesic.

\section{Response}

In the CAEP guidelines, barbiturates are listed as medications for sedation, not as medications for analgesia. "Nowhere do we suggest that barbiturates are analgesics. On the contrary, we state that they do not provide analgesia. I wouldn't call this a factual error."

3. We suggested that ketamine rather than propofol is the drug of choice for asthmatic induction.

\section{Response}

"Propofol may or may not be the drug of choice for asthmatic induction, but
I don't know any emergency physicians who are permitted to use it. Perhaps this is an issue we can further explore."

\section{Action}

A section of the CAEP guidelines, which referred to the use of specific agents for sedation and analgesia, was eliminated from the final guidelines.

\section{CAS concern}

The reviewer felt that it was inappropriate to provide information about specific drugs in the guidelines. (The second draft of the guidelines included a discussion of commonly used drugs for ED sedation and analgesia.) Response

"While we're not sure that information is ever evil, or that it is 'wrong' to make information available to physicians who might use it, this section could conceivably be removed from the Guidelines."

\section{Action}

This section, discussing the use of specific pharmacologic agents, was eliminated from the guidelines.

\section{CAS concern}

The reviewer suggests that our guidelines contradict yours.

\section{Response}

"After looking in detail at the concerns specified by CAS reviewers, we are not convinced that this is true."

\section{Action}

None taken.

After addressing the CAS concerns, the following summary statement was provided to help CAS Standards Committee members appreciate the ED perspective when deciding whether or not to endorse the CAEP guidelines.

"While we recognize that your primary concern, like ours, is safety, we are concerned that you and your reviewers do not see the emergency medicine perspective. It is important 
to communicate several things to you:

1. Sedation and analgesia are and will continue to be essential components of emergency medicine.

2. The vast majority of our "cases" involve brief, light sedation, which emergency physicians do not regard as "anesthesia." Consequently, if they are aware of guidelines developed by anesthetists (they probably aren't, since they follow your literature about as closely as you follow ours), they are unlikely to take those guidelines to heart.

3. Currently there is wide practice variation across the country. Standards are necessary. Like anyone else, when it comes to defining practice standards on our home ground, we tend to look to our own. Emergency practitioners are most likely to accept guidelines developed by people who understand the disease spectrum we see, the skills we possess, the procedures we perform, and the conditions we work under. This is why we feel it is important to develop and promote our own guidelines, though we believe them to be compatible with yours in virtually every way.

4. We acknowledge and value your expertise. We would like to have you remain a part of this process, which will increase the safety of procedures that are done daily in emergency departments across Canada.

We are willing to make any changes or revisions that will improve our guidelines, and we hope you will reconsider the draft document in light of our comments above.

The CAS subsequently elected not to endorse CAEP's sedation guidelines. In their final communication to us, they indicated that our guidelines did not stress that general anesthesia is rarely required in the ED. They then provided us with a "practical" definition for general anesthesia in the ED. By the new definition, patients would be considered to be under general anesthesia if they fulfilled any of the following criteria:

- spontaneously closed eyes,

- lack of appropriate response to questions posed in a conversational tone of voice,

- apparent indifference to the environment.

Based on this new definition of general anesthesia, it is presumably reasonable for ED physicians to continue to sedate patients for painful procedures, but we must ensure that those patients keep their eyes open at all times.

It will be a difficult standard to meet.

\section{References}

1. Donald D. Emergency department sedation [letter]. CJEM 1999;1(2):92.

2. Innes G, Murphy M, Nijssen-Jordan C, Ducharme J, Drummond A. Procedural sedation and analgesia in the emergency department. Canadian Consensus Guidelines. J Emerg Med 1999;17:145-56.

3. Joint Commission on Accreditation of
Healthcare Organizations (JCAHO). Accreditation Manual for Hospitals. Vol. 1. Chicago (IL): JCAHO, 1993. p. 165-70.

4. Sacchetti A, Schafermeyer R, Gerardi M, Graneto J, Fuerst RS, Cantor R, et al. Pediatric sedation and analgesia. Ann Emerg Med 1994;23:237-50.

5. American Society of Anesthesiologists. Practice guidelines for sedation and analgesia by non-anesthesiologists. Anesthesiology 1996;84:459-71.

6. NIH Consensus Conference. Anesthesia and sedation in the dental office. JAMA 1985;254:1073-6.

7. Holzman RS, Cullen DJ, Eichhorn JH, Philip JH. Guidelines for sedation by nonanesthesiologists during diagnostic and therapeutic procedures. The Risk Management Committee of the Department of Anesthesia of Harvard Medical School. J Clin Anesth 1994;6: 265-7.

8. American Academy of Pediatrics Committee on Drugs. Guidelines for monitoring and management of pediatric patients during and after sedation for diagnostic and therapeutic procedures. Pediatrics 1992;89(6):1110-5.

9. Bell GD, McCloy RF, Charlton JE, Campbell D, Dent NA, Gear MW, et al. Recommendations for standards of sedation and patient monitoring during gastrointestinal endoscopy. Gut 1991; 32:823-79.

10. Wright SW, Chudnofsky CR, Dronen SC, Kothari R, Birrer P, Blanton DM, et al. A comparison of midazolam and diazepam for conscious sedation in the emergency department. Ann Emerg Med 1993;22:201-5. 